\title{
Institutions and Government Growth: A Comparison of the 1890 s and the 1930s
}

\author{
Thomas A. Garrett, Andrew F. Kozak, and Russell M. Rhine
}

\begin{abstract}
Statistics on the size and growth of the U.S. federal government, in addition to public statements by President Franklin Roosevelt, seem to indicate that the Great Depression was the primary event that caused the dramatic growth in government spending and intervention in the private sector that continues to the present day. Through a comparison of the economic conditions of the 1890s and the 1930s, the authors argue that post-1930 government growth in the United States is not the direct result of the Great Depression, but rather is a result of institutional, legal, and societal changes that began in the late 1800s. Thus, the Great Depression did likely trigger increases in government spending and regulatory involvement, but historical factors produced the conditions that tended to lend permanence to the growth of government that occurred during the Great Depression. (JEL N41, N42, H2, H5, B1)
\end{abstract}

Federal Reserve Bank of St. Louis Review, March/April 2010, 92(2), pp. 109-19.

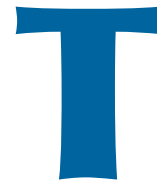

hroughout the eighteenth and nineteenth centuries, a limited federal government existed in the United States. The federal government had essentially no involvement in regulating the private sector and few goods were provided publicly, even during times of war and economic contraction. At the same time, taxes at the national level were few and tax rates remained relatively low. However, a limited federal government did not last. The twentieth century saw increased federal government regulation, the creation of new agencies, the expansion of existing agencies, the implementation of new taxes, increases in existing taxes, and an increase in government spending.

The dramatic growth in government spending started at the beginning of the Great Depression. For example, annual federal government per capita spending averaged \$125 from 1792 to 1929 with no trend increase. However, real federal government per capita spending rose from roughly
$\$ 250$ in 1930 to nearly $\$ 9,200$ in $2007 .{ }^{1}$ In addition, federal government spending rose from 3 percent of U.S. gross domestic product (GDP) in 1929 to over 24 percent of GDP by 2009. The high level of unemployment, the decrease in national income, and the falling price level during the Great Depression seemingly caused the federal government to intervene to resolve this crisis. President Franklin Roosevelt stated in his 1933 inaugural address, "Our greatest primary task is to put people to work...It can be accomplished in part by direct recruiting by the government itself."2 In fact, his desire to use government intervention as a quick remedy to the Depression was so strong that he also stated in his address that if Congress failed to follow his recommended poli-

\footnotetext{
1 Per capita spending figures are stated in year-2000 dollars. Historical statistics on GDP and government spending are from the U.S. Census and the Office of Management and Budget, Budget of the United States Government, Historical Tables.

2 Rosenman (1938).
}

Thomas A. Garrett is an assistant vice president and economist at the Federal Reserve Bank of St. Louis. Andrew F. Kozak and Russell M. Rhine are associate professors of economics at St. Mary's College of Maryland. Lesli Ott provided research assistance.

(C) 2010, The Federal Reserve Bank of St. Louis. The views expressed in this article are those of the author(s) and do not necessarily reflect the views of the Federal Reserve System, the Board of Governors, or the regional Federal Reserve Banks. Articles may be reprinted, reproduced, published, distributed, displayed, and transmitted in their entirety if copyright notice, author name(s), and full citation are included. Abstracts, synopses, and other derivative works may be made only with prior written permission of the Federal Reserve Bank of St. Louis. 


\section{Figure 1}

\section{Real per Capita Federal Receipts and Expenditures (1792-2009)}

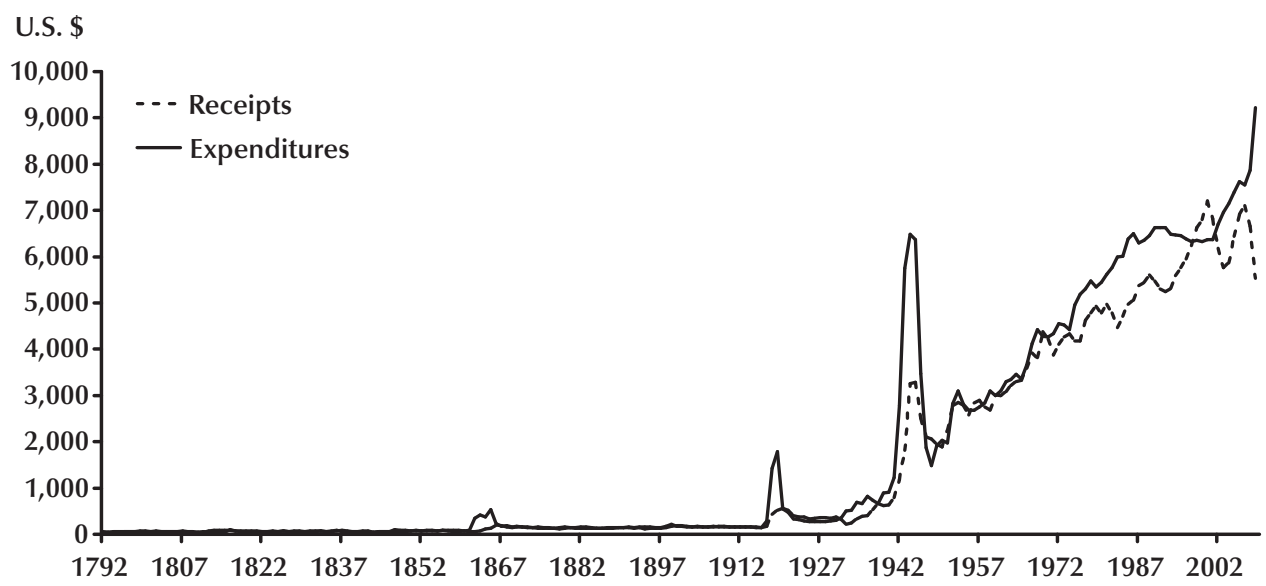

cies, he would request "broad Executive power to wage war against the emergency as great as the power that would be given to me if we were in fact invaded by a foreign foe." Although these statements indicate a strong desire to strengthen government powers to soften the economic downturn, the severity of the economic contraction during the Depression cannot necessarily be deemed the proximate cause of the rapid growth in government spending since then.

In the 1890s a series of recessions neared the severity of the Great Depression and yet there was virtually no response by the federal government. The average annual increase in per capita government spending was 3.3 percent in the $1890 \mathrm{~s}$ and 12.1 percent in the 1930s. The total percentage increase in per capita government spending was 28 percent for the 1890s and 131 percent for the 1930s. Clearly, something in the United States during the 1930s differed from conditions in the 1890s that spurred the federal government to react to the economic downturn.

This paper explains the growth in the federal government in the United States since the 1930s. The size of government refers not only to spending, but also to the number of regulations, agencies, and laws. We compare and contrast the two worst decades of economic activity in U.S. history: the 1890s and the 1930s. Although both decades were marked by substantial economic contractions, they also occurred during two very different political and social climates. The 1890s was a time when the federal government did not attempt to smooth the business cycle through activist policy, whereas the 1930s was a time of unprecedented federal government intervention in the economy that continues to this day. We suggest that post1930 government growth is not due solely to the Great Depression, but rather is a result of institutional, legal, and societal changes that began decades earlier.

\section{HISTORICAL BACKGROUND}

The question as to the appropriate size and role of the federal government in the United States has its roots in the 1770s and 1780s during the writing of the Articles of Confederation and the U.S. Constitution. The debate then was reflected in the writings of the Federalists and the AntiFederalists. The Federalists supported the Constitution and generally viewed the government as playing a greater role in society than the Anti-Federalists. The Anti-Federalists worried that the organization of the federal government, as written in the Constitution, gave the govern- 
ment too much power and could result in monarchy. Despite the debate between these groups, government spending remained low for more than a century after ratification of the U.S. Constitution. Figure 1 shows no change in the trend of per capita federal spending from the late 1700s through the 1920s. The only increases during that period followed the Civil War and World War I.

In addition to federal expenditures, another measure of the size and scope of the federal government is the number of executive cabinet departments. This number changed little from the late 1700s through the 1920s. In 1789 there were four cabinet departments; by the end of the nineteenth century only two more had been added. However, since the beginning of the twentieth century another 10 departments have been added. Of those 10, the Department of Commerce and the Department of Labor were created before the 1930s. Table 1 lists the departments and years they were created.

There is little debate that the Great Depression was the worst economic period in U.S. history. However, economic data suggest that, to date, the decade of the 1890s was the second-worst economic period in U.S. history. Higgs (1987, p. 77) states, "Except [for] the Civil War, no crisis of the nineteenth century challenged America's political and economic order so profoundly as that of the mid-1890s."

According to the National Bureau of Economic Research, the United States had three separate recessions between 1890 and $1898 .{ }^{3}$ As shown in Figure 2, the 1890s experienced some years of increasing GDP and some years of decreasing GDP. Due in part to the years of growth, the country was seen as experiencing brief economic expansions. However, these expansions likely went unnoticed by a substantial portion of the population because the unemployment rate remained high and prices were stagnant or falling.

Other macroeconomic statistics suggest that the recessions of the 1890s approached the severity of the Great Depression. The national unemployment rate from 1890 through 2009 is shown in

3 See www.nber.org/cycles.html for National Bureau of Economic Research recession dates.

\section{Table 1}

\section{Cabinet Departments: Year Established}

\begin{tabular}{lc} 
Department & Year established \\
\hline State & 1789 \\
Treasury & 1789 \\
Justice & 1789 \\
Defense* & 1789 \\
Interior & 1849 \\
Agriculture & 1889 \\
Commerce & 1913 \\
Labor & 1913 \\
Health and Human Services & 1953 \\
Housing and Urban Development & 1965 \\
Transportation & 1966 \\
Energy & 1967 \\
Education & 1979 \\
Veterans Affairs & 1987 \\
Environmental Protection Agency & \\
Homeland Security & 1990
\end{tabular}

NOTE: *The date refers to the Department of War. The Department of Defense was officially created in 1949: The Department of War (1789), the Department of the Navy (1798), the Department of the Army (1947), and the Department of the Air Force (1947) were all reorganized under the Department of Defense in 1949 (see www.dod.gov). ${ }^{+}$Cabinet-level rank under George W. Bush. See www.whitehouse.gov/government/cabinet.html.

SOURCE: Cabinet Department websites.

Figure 3: There were six consecutive years of double-digit unemployment from 1893 through 1898, with unemployment reaching its highest point-18.4 percent-in 1894. Only during the Great Depression did the unemployment rate ever exceed 18.4 percent.

In addition to reductions in GDP and increases in the unemployment rate, the general price level fell 8.3 percent between 1890 and 1899. ${ }^{4}$ As with the unemployment rate, the severity of the deflation was greater during the 1930s when the price level fell nearly 17 percent between 1930 and 1939. The duration of falling prices in the $1890 \mathrm{~s}$ is consistent with negative economic growth.

4 Source: Historical Statistics of the United States (online database: http://hsus.cambridge.org). 
Figure 2

\section{Change in Real per Capita GDP (1890-98)}

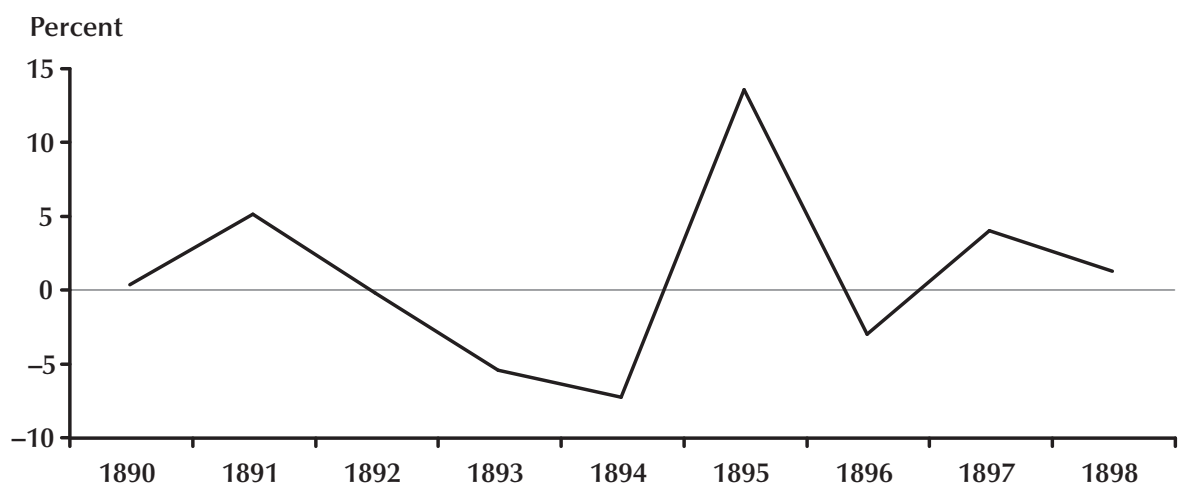

It is unlikely that the hardships of the 1890s went unnoticed by the federal government, but laws, institutions, and the public's view on the role of government had to change before any government intervention would occur. President Grover Cleveland clearly stated his view on the limited role of the federal government when he vetoed the Texas Seed Bill in 1887, a bill that would have authorized the federal government to purchase and distribute seed grain to Texas farmers:

I can find no warrant for such an appropriation in the Constitution; and I do not believe that the power and duty of the General Government ought to be extended to the relief of individual suffering which is in no manner properly related to public service or benefit. A prevalent tendency to disregard the limited mission of this power and duty should, I think, be steadily resisted, to the end that the lesson should be consistently enforced that, though the people support the Government, the Government should not support the people. ${ }^{5}$

Why did this view of a limited role for government involvement not last? As discussed later, institutional changes that occurred before the 1930 s but not before the 1890s laid the foundation for greater government growth. Following

5 Congressional Record (1887).
Holcombe (2005), we categorize the changes as consistent with one of three existing theories on government growth: path dependency, budget maximization and taxation, and rational choice. Hindsight allows us to identify the events that served as the necessary conditions for the change in the size and growth of government. Without these events, the Great Depression may have had no lasting effect on public policy; but with these events, the growth in government spending was inevitable.

\section{EXPLAINING GOVERNMENT SIZE AND GROWTH}

\section{Path Dependency}

Theories of path dependency state that government spending is time dependent and that removal of programs is difficult once a government agency or program is in place. Government spending has considerable inertia, and changes in the level of real government spending from year to year are more likely to be increases than decreases. Path dependency explains why government spending continues to grow seemingly independent of the state of the economy (Holcombe, 2005).

The path dependency theory of government growth has two dimensions. One dimension is 


\section{Figure 3}

\section{U.S. Unemployment Rate (1890-2009)}

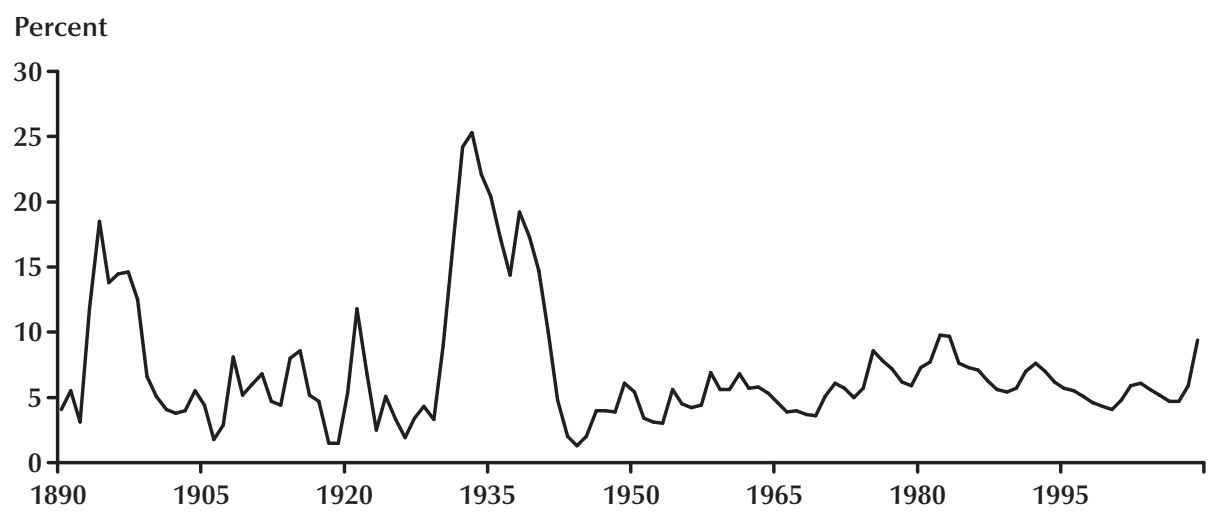

the status quo bias, which states that if people are given a variety of choices, they have a preference toward continuity as opposed to change. In the government growth literature this translates into the electorate's preference to continue government programs, even though voters may have originally objected to their formation (Holcombe, 2005). In government spending parlance, ratcheting, a second dimension of path dependency, is the hypothesis that government spending increases remain after a crisis to prevent future crises of a similar nature (Peacock and Wiseman, 1961; Rasler and Thompson, 1985; Higgs 1987; Holcombe, 1996, 2005). This hypothesis neatly explains the increases in spending after the Civil War and World War I; however, it is difficult to identify upward ratchets in government spending since 1930 because government spending has increased continuously (Holcombe, 1996). The primary limitation of the path dependency literature is that it does not explain why the Great Depression caused the trend of government spending to change when the numerous crises during the preceding 150 years, including the 1890 s, did not.

\section{Budget Maximization and Taxation}

Holcombe (2005) provides one possible explanation for the fact that per capita real government spending stayed essentially unchanged from 1792 through the 1920s. He argues that the primary constraint on government spending is the amount of tax revenue that it receives. This constraint on spending is supported by his earlier work (Holcombe, 1999), in which he shows the relationship between federal government benefits paid to Civil War veterans and the size of the federal government budget. In 1870, per capita spending on veterans was $\$ 7.20$; this amount grew for the next 23 years to a high of $\$ 34.39$ in $1893 .^{6}$ For the entire 23-year period, the federal government had a budget surplus and in 1894, the first of six consecutive years of deficits, the benefits to veterans fell because the balanced budget constraint was reached and the government limited spending to prevent the deficit from growing.

A balanced budget constraint and limited tax revenue can explain the lack of substantial federal government growth before the 1930s. Federal government taxes before the early twentieth century remained low and tax bases were few. Under the Articles of Confederation, funds for the federal government came from voluntary donations from the state governments. The inadequacy of this method of federal government financing was soon realized, and the federal government was given the power to levy excise taxes and customs duties after the ratification of the U.S. Constitution in

${ }^{6}$ Veteran spending is in per capita 1990 dollars. 
1788. The excise taxes initially were imposed on distilled spirits, tobacco and snuff, refined sugar, carriages, property sold at auction, and some legal documents. Later, during the War of 1812, additional goods were subject to excise taxes and customs duties were increased. ${ }^{7}$

Throughout the first half of the 1800s it became clear to those in the South that they were subject to greater customs duties because they imported most of their manufactured goods from the northern states or abroad. This inequity in taxation contributed to the tensions between the northern and southern states before the Civil War (Holcombe, 1992; Holcombe and Lacombe, 1998). During the Civil War, the federal government passed the Revenue Act of 1861, which imposed the first federal income tax: a 3 percent tax on all income over \$800. In 1862, the federal government imposed new excise taxes on playing cards, gunpowder, feathers, telegrams, iron, leather, pianos, yachts, billiard tables, drugs, patent medicine, and whiskey. At that time, the deduction was decreased from $\$ 800$ to $\$ 600$ and the tax rate was increased to 5 percent on all income over $\$ 10,000$. The income tax was removed in 1872 .

After the removal of the income tax, the federal government once again relied on various excise taxes for funds; for the next 22 years, the federal tax code did not include taxes on income. However, in 1894 the federal government imposed another income tax. This time, however, the Supreme Court deemed the tax unconstitutional. It was not until 1913 that the federal government was able to effectively impose another income tax through the ratification of the Sixteenth Amendment to the Constitution. The first income tax rates were extremely low by today's standardsbetween 1 percent and 7 percent-and the 7 percent tax bracket was for income in excess of $\$ 500,000$ (more than $\$ 10$ million in 2009 dollars). However, the low tax rates did not last long; by 1932 the lowest tax bracket was 4 percent and the highest tax bracket, which applied to incomes over \$1 million, was 63 percent.

\footnotetext{
7 See the U.S. Treasury "Fact Sheets: Taxes" for the history of the U.S. tax system

(www.treas.gov/education/fact-sheets/taxes/ustax.shtml).
}

With the passage of the Sixteenth Amendment the government had a new source of income that substantially reduced its budget constraint. Under the model of bureaucracy proposed by Niskanen (1971) and the Leviathan model of government suggested by Brennan and Buchanan (1980), the government will take advantage of any opportunity to increase tax revenue to increase the funding of existing programs and to fund new government programs. Figure 1 shows that a close relationship between federal government spending and revenue has persisted over time.

The limited source of revenue serves as a self-imposed budget constraint that prevents the use of increased government spending to soften the impact of a recession. Holcombe and Mills (1995) argue that, without tax increases, the only alternative means to fund an increase in spending is through an increase in deficits, and deficit spending is constrained in that it is often politically unpopular. With the passage of the Sixteenth Amendment, the government was in a much better position to increase spending during the Great Depression than during the economic downturn of the 1890s. Holcombe and Lacombe (1998) claim that the government growth that dominated the twentieth century could not have occurred without the Sixteenth Amendment.

\section{Rational Choice and a New Political Philosophy}

The rational choice theory of government growth states that the government grows because citizens demand more government intervention. Based on the classic works of Hotelling (1929) and Downs $(1957,1961)$, the median voter theorem states that the level of government tends to reflect the preference of the median voter. ${ }^{8}$ The late nineteenth and early twentieth century was a time of shifting social political philosophy and thus a change in the view of the median voter.

\footnotetext{
8 If voters are ranked by political ideology with the most liberal on one side and the most conservative on the other side, the level of government that is provided reflects the view of the person in the middle, or the "median voter." See also Peltzman (1980); Meltzer and Richard (1978, 1981, 1983); Kristov, Lindert, and McClelland (1992); Becker (1983); and Wittman (1989, 1995).
} 
The shift in philosophy must be partly attributed to the writings of Karl Marx and, to a lesser extent, Henry George. Marx's Communist Manifesto and Das Kapital, published in 1848 and 1867, respectively, stressed that unemployment and poverty will always exist in a capitalist society. Marx also argued that business owners lived well while the working class lived poorly. To eliminate this inequity he argued for the nationalization of industry "to promote working-class interests rather than those of the landed aristocracy, industrialists and financiers" (Hudson, 2008). Marx's idea of greater income equality, financial security, and social justice seemed to resonate with the working class. George drew similar appeal with his idea of a single tax on land that would replace all other taxes. His Progress and Poverty (1879) was widely read and influenced many industrial and labor reformers. Although he was not a Socialist, George did believe that it was necessary for the government to operate monopolies and basic infrastructure (Hudson, 2008). Together, these writings contributed to the leftward movement of the median voter and likely fueled the demand for federal regulation of the private sector, the growth in labor movements, the development of the U.S. Socialist Party, and a greater redistribution of income and wealth.

The result of this swing in philosophy is best captured in the social development now referred to as the Populist Movement and the Progressive Movement of the late nineteenth and early twentieth centuries. These movements represented the changing view of the relationship between the individual and the state in which a desire for a more active role of government in the economy developed. As the U.S. economy transformed itself from a system of many small, competitive units into a system of seemingly fewer firms of greater size, concern grew that the large corporations were becoming too rich and, importantly, too powerful. This concern is clearly presented in the founding document of the Populist Party adopted on July 4, 1892—the Omaha Platform. ${ }^{9}$

\footnotetext{
9 See http://history.missouristate.edu/wrmiller/Populism/texts/ Documents/Omaha Platform.htm for the entire text of the Omaha Platform.
}

The Omaha Platform addressed three key issues: finance, transportation, and land. First, on the issue of finance, it stated that a national currency issued by the government should be distributed directly to the people "without the use of banking corporations." Second, it declared that "the government should own and operate the railroads in the interest of the people." Finally, it stated that land "should not be monopolized for speculative purposes" and that "All land now held by railroads and other corporations in excess of their actual needs, and all lands now owned by aliens should be reclaimed by the government and held for actual settlers only."

Additionally, government planning during the First World War and the introduction of "scientific management" by Frederick Winslow Taylor (Taylor, 1912) reinforced the government's ability to partly plan the economy. World War I required the government to be more involved in allocating resources to meet the needs of fighting the war; specifically, the government assumed control over the railroad industry. With the successful outcome of the war, the government was seen as capable of managing some aspects of the economy. Put more broadly, government planning and control could be a positive force in marshaling society's resources to achieve its goals, lending further credence to Taylor's theory. Under Taylor's approach, by applying the scientific method and empirical analysis to production techniques, firms could plan and better manage their production outcomes. In other words, scientific management could help a firm become more efficient. Therefore, Taylor's analysis of private sector production efficiency could also be used by public sector managers to help reduce the booms and busts of the business cycle (Bruce and Nyland, 2001).

Growing public support for greater government intervention, accompanied by a sense of unfair business practices by large corporations, indicated a clear desire for change in the country. This change came in the form of regulations at the federal government level that increased the government's involvement in the private sector. The first regulations were designed to eliminate price discrimination in specific industries and to preserve the competitive environment. For 
example, the Interstate Commerce Act, passed in 1887, created the Interstate Commerce Commission and federally regulated the railroad industry. At that time, railroad companies had little or no competition on some routes and subsequently practiced price discrimination (Friedlaender, 1969, pp. 11-12). The Act required that railroads eliminate price discrimination, publish their fares, and charge a "reasonable and just" fare. The railroad industry was the first industry to be regulated by the federal government. Three years later in 1890, the Sherman Antitrust Act was passed: It made trusts illegal to ensure competition.

The banking and financial sectors also experienced greater government intervention early in the twentieth century. The dominant legislative act was the creation of a central bank through the implementation of the Federal Reserve Act of 1913. Specifically stated, the purpose of the Federal Reserve Act is "To provide for the establishment of Federal reserve banks, to furnish an elastic currency, to afford means of rediscounting commercial paper, to establish a more effective supervision of banking in the United States, and for other purposes." 10 Before 1913, the only time the U.S. government established central banks was to aid in the financing of wars. In 1791, the First Bank of the United States was chartered to help manage the debt of the Revolutionary War. The Second Bank of the United States was chartered in 1816, in part to help manage the debt of the War of 1812. Both bank charters were for 20 years and were not renewed when the charters expired.

Other examples of greater private sector regulation are the Food and Drugs Act of 1906 and the creation of the Federal Trade Commission in 1914. The Food and Drugs Act prohibited interstate transport of illegal food and drugs, banned the addition of specific ingredients, and regulated product labeling. The purpose of the Federal Trade Commission was to prevent unfair methods of competition, seek relief for injured consumers, regulate trade, conduct investigations of commerce, and make reports and legislative recom-

\footnotetext{
${ }^{10}$ From "History of the Federal Reserve"

(www.federalreserveeducation.org/fed101/history/).
}

mendations to Congress. These new regulatory agencies are further evidence of the changing role of the federal government and its move to becoming the "guardian of the economic wellbeing of its citizens" (Holcombe and Lacombe, 1998, p. 144).

In addition to the federal government's entry in regulating various industries within the private sector, the government also began to regulate the use of labor in the late 1800s. Although labor unions had existed to some degree in the United States since the signing of the Declaration of Independence, by the late nineteenth century they were growing in number and influence, as suggested by the formation of the American Federation of Labor in 1886. The coming years saw several union-led strikes that received national publicity, most notably the Pullman Strike outside Chicago in 1894 and the coal miners' strike in northeastern Pennsylvania in 1902. Union lobbying efforts influenced Congress to create the Bureau of Labor in 1884 and the U.S. Department of Labor in 1913 (Grossman, 1973). The purpose of the Department of Labor was "to foster, promote, and develop the welfare of the wage earners of the United States, to improve the working conditions, and to advocate their opportunities for profitable employment."11

The 1894 Pullman Strike was led by Eugene Debs, who in 1898 organized the Social Democratic Party of America and in 1901 led the organization of the Socialist Party of the United States of America. Debs, who moved up through the ranks of the labor unions, and the Socialist Party both had substantial public support; and Debs ran for president of the United States as a Socialist in 1900, 1904, 1908, 1912, and 1920. His success as a presidential candidate peaked in 1912 when he received 6 percent of the popular vote. This small percentage may not seem substantial, but it is evidence of changing views on the role of government and development of a new political philosophy.

In addition to the electorate changing its views on the role of government, the electorate itself

\footnotetext{
${ }^{11}$ From "Public Law 426-62: An Act to create a Department of Labor" (www.dol.gov/oasam/programs/history/organact.htm).
} 
was also changing. In 1920, passage of the Nineteenth Amendment gave women the right to vote. While 29 of the 48 states had already given women this right before 1920, all but 4 of the 29 had done so since the turn of the century. Lott and Kenny (1999) explain that the overall voting pattern of women is more liberal than men's and as more women participated in elections, demand for government intervention in the economy increased. The more liberal views of women added to the changing view of government's role in society, thereby further reinforcing the new political philosophy of greater government intervention.

Within this new political philosophy came greater demand to make the government more accountable to the voters (Holcombe and Lacombe, 1998). To do so, the electoral process had to be changed. While the president and representatives in the U.S. Congress had always been elected through public elections, senators had not. The Constitution originally stated that the senators from each state were to be chosen by the state legislators. This legislative organization was written into the Constitution to prevent excessive democracy because "a democratic majority could overrun individual freedom just as surely as a monarch" (Holcombe and Lacombe, 1998, p. 148).

In pushing for greater government accountability, the voters demanded public elections for senators. The Seventeenth Amendment to the Constitution, ratified in 1913, stated that the senators of each state were to be elected by the people of the state. This Amendment greatly increased the power of the voters over the government, and beginning with the election of 1914, the voters determined the makeup of both houses of Congress.

In aggregate, the passage of regulatory acts over the private sector, the labor movement and its lobbying success, the Socialist movement and its growing political presence, the change in the voting franchise, and the change in the legislative electoral process are all evidence of a massive ideological shift that contributed to the departure from the limited role of government that had prevailed for more than a century. These events of the late 1800s and early 1900s created many of the institutions and laws that contributed to the growth in federal government spending and private sector intervention since the 1930s. Because these institutions and laws were not firmly in place in the 1890s, the federal government was unable to increase spending. Higgs (1987, p. 78) states more generally that government grows "only under favorable conditions, and such conditions did not exist in the 1890s."

\section{CONCLUSION}

Federal government spending and intervention in the private sector have increased steadily since the 1930s. While increased spending to reduce the effects of the Great Depression seems like a plausible explanation for the change in federal spending given the simultaneity of both events, the root cause of government growth is much more complicated. The complexity is evident in the fact that the trend in federal government spending did not change for the initial 150 years of the United States, including the severe recessions of the 1890s. This lack of growth was primarily due to a general view that the federal government should play a small role in society.

The view of a minimalist federal government during the eighteenth and nineteenth centuries was likely based on a strict interpretation of the Constitution regarding the powers of the U.S. Congress (e.g., the Preamble to the Constitution and Article 1, Section 8). In a famous letter to President Washington, Thomas Jefferson stated the importance of the federal government maintaining its limited mandates. ${ }^{12}$ This view of limited government prevailed until the late 1800s. However, beginning with the regulation of the railroads in 1887, the federal government slowly moved in the direction of supervisor and manager

\footnotetext{
12 Thomas Jefferson wrote the following on February 15, 1791, in a letter to President George Washington in reference to the creation of the First Bank of the United States: "I consider the foundation of the Constitution as laid on this ground: That 'all powers not delegated to the United States, by the Constitution, nor prohibited by it to the States, are reserved to the States, or to the people [10th Amendment].' To take a single step beyond the boundaries thus specially drawn around the powers of Congress is to take possession of a boundless field of power, no longer susceptible of any definition" (Jefferson's original letter is shown at www.loc.gov/exhibits/jefferson/images/vc129.jpg).
} 


\section{Garrett, Kozak, Rhine}

of the private sector. Federal government regulation steadily increased over the next 30 years. In addition, voters began to choose candidates who promised greater federal government involvement in the private sector. The first two decades of the twentieth century saw unprecedented changes in federal government regulation, taxation, the electoral process, and the public's demand for federal intervention in the private sector.

The government expanded in the 1930s for two reasons: First, its source of funds had increased with passage of the Sixteenth Amendment. With all barriers to the imposition of a personal income tax eliminated, the federal government had a substantial increase in its source of funds, thereby allowing increased spending. The second reason was a national ideological shift toward greater government. This shift was reflected by, and perhaps motivated by, the writings of Karl Marx and Henry George in the mid-1800s and later by women's increased participation in the electoral process. The implication of this shift is evident in the growth of the labor movement and the Socialist movement in the late nineteenth and early twentieth centuries. The status quo bias and upward ratchets in spending explain why government spending never retreats once implemented.

These ideological, legal, and societal changes resulted in increased federal government regulation over various industries and creation of institutions that set the stage for future government expansion. These events made the 1930s' growth in spending possible and enabled the government to swiftly alter the trend in spending and taxation. The severity of the Great Depression was not the sole catalyst that spurred government spending. If economic conditions were the only reason for government growth during the Great Depression, then the 1890s, too, would have experienced significant intervention by the federal government.

\section{REFERENCES}

Becker, Gary S. "A Theory of Competition among Pressure Groups for Political Influence.” Quarterly Journal of Economics, August 1983, 98(3), pp. 371-400.

Brennan, Geoffrey and Buchanan, James M. The Power to Tax: Analytical Foundations of a Fiscal Constitution. Cambridge, MA: Cambridge University Press, 1980.

Bruce, Kyle and Nyland, Chris. "Scientific Management, Institutionalism, and Business Stabilization: 19031923.” Journal of Economic Issues, December 2001, 35(4), pp. 955-78.

Congressional Record. 49th Congress, 2nd session, 1887, Volume XVIII, Part II, p. 1885.

Downs, Anthony. An Economic Theory of Democracy. New York: Harper and Row, 1957.

Downs, Anthony. “In Defense of Majority Voting.” Journal of Political Economy, April 1961, 69(2), pp. 192-99.

Friedlaender, Ann F. The Dilemma of Freight Transport Regulation. Washington, DC: Brookings Institution, 1969.

Grossman, Jonathan. “The Origin of the U.S. Department of Labor.” Monthly Labor Review, March 1973, 96(3), pp. 3-7.

Higgs, Robert. Crisis and Leviathan. New York: Oxford University Press, 1987.

Holcombe, Randall G. "The Distributive Model of Government: Evidence from the Confederate Constitution." Southern Economic Journal, January 1992, 58(3), pp. 762-69.

Holcombe, Randall G. "The Growth of the Federal Government in the 1920s.” Cato Journal, Fall 1996, 16(2), pp. 175-99.

Holcombe, Randall G. "Veterans Interests and the Transition to Government Growth: 1870-1915." Public Choice, June 1999, 99(3-4), pp. 311-26. 
Holcombe, Randall G. "Government Growth in the Twenty-First Century.” Public Choice, July 2005, 124(1-2), pp. 95-114.

Holcombe, Randall G. and Lacombe, Donald J. "Interests versus Ideology in the Ratification of the 16th and 17th Amendments." Economics and Politics, July 1998, 10(2), pp. 143-59.

Holcombe, Randall G. and Mills, Jeffrey A. "Politics and Deficit Finance." Public Finance Quarterly, October 1995, 23(4), pp. 448-66.

Hotelling, Harold. "Stability in Competition.” Economics Journal, 1929, 39, pp. 41-57.

Hudson, Michael. "Henry George’s Political Critics.” American Journal of Economics and Sociology, January 2008, 67(1), pp. 1-45.

Kristov, Lorenzo; Lindert, Peter and McClelland, Robert. "Pressure Groups and Redistribution.” Journal of Public Economics, July 1992, 48(2), pp. 135-63.

Lott, John R. Jr. and Kenny, Lawrence W. "Did Women’s Suffrage Change the Size and Scope of Government?” Journal of Political Economy, December 1999, 107(6 Part 1), pp. 1163-98.

Meltzer, Allan H. and Richard, Scott F. "Why Government Grows (and Grows) in a Democracy." Public Interest, 1978, 52(1), pp. 111-18.

Meltzer, Allan H. and Richard, Scott F. “A Rational Theory of the Size of Government.” Journal of Political Economy, October 1981, 89(5), pp. 914-27.

Meltzer, Allan H. and Richard, Scott F. "Tests of a Rational Theory of the Size of Government.” Public Choice, 1983, 41(3), pp. 403-18.

Niskanen, William A. Bureaucracy and Representative Government. Chicago: Aldine-Atherton, 1971.

Peacock, Alan T. and Wiseman, Jack. The Growth of Government Expenditures in the United Kingdom. Princeton, NJ: Princeton University Press, 1961.

Peltzman, Sam. "The Growth of Government." Journal of Law and Economics, October 1980, 23(2), pp. 209-87.

Rasler, Karen A. and Thompson, William R. "War Making and State Making: Governmental Expenditures, Tax Revenues, and Global Wars.” American Political Science Review, June 1985, 79(2), pp. 491-507.

Rosenman, Samuel. The Public Papers of Franklin D. Roosevelt, Volume Two: The Year of Crisis, 1933. New York: Random House, 1938, pp. 11-16.

Taylor, Frederick W. Principles of Scientific Management. Westport, CT: Greenwood Press, 1912.

Wittman, Donald A. "Why Democracies Produce Inefficient Results." Journal of Political Economy, December 1989, 97(6), pp. 1395-424.

Wittman, Donald A. The Myth of Democratic Failure. Chicago: University of Chicago Press, 1995. 
